\title{
RURAL TERRITORIES AND FOOD TOURISM - EXPLORING THE VIRTUOUS BONDS THROUGH A SYSTEMATIC LITERATURE REVIEW
}

\author{
Elisabete Figueiredo, Teresa Forte, Celeste Eusébio ${ }^{1}$
}

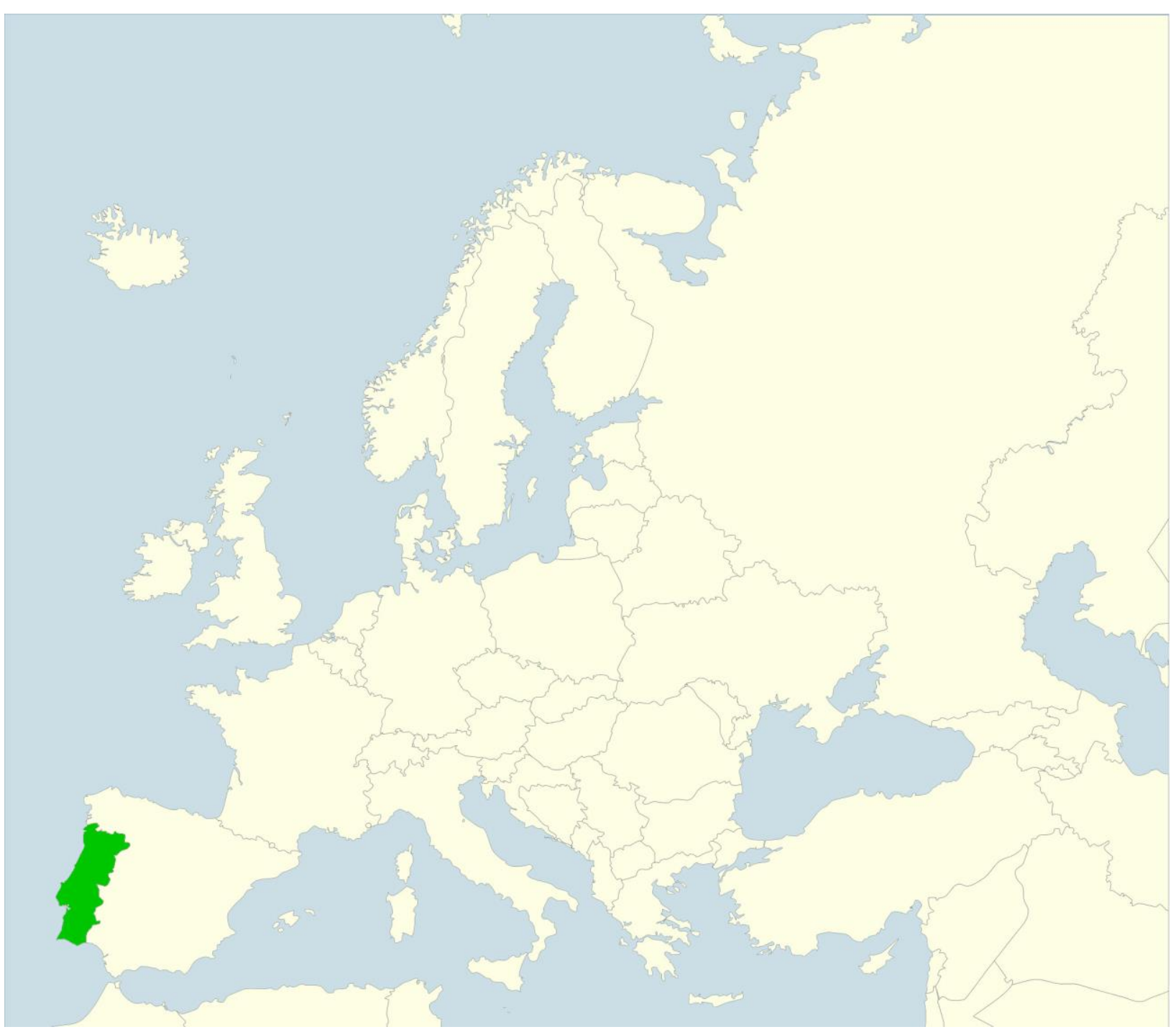

${ }^{1}$ Elisabete Figueiredo, PhD; Associate Professor with habilitation; e-mail: elisa@ua.pt, ORCID: 0000-0001-7170-3369, corresponding author; Teresa Forte, PhD; e-mail: teresaforte@ua.pt. ORCID: 0000-0003-3817-7410; Celeste Eusébio, PhD; Associate Professor, e-mail: celeste.eusebio@ua.pt, ORCID: 0000-0002-2220-5483. University of Aveiro, Portugal. 
Abstract: Although studies on food and tourism have gained terrain within tourism research, especially in the last decade, the connections of food tourism with rural territories have remained underexplored. This is particularly significant in the context of an increasing recognition that food should be understood as a distinguishing feature of rural tourism destinations, at the same time as displaying specific heritage and traditions as and contributing to the development of rural territories. The intention of this article is to shed light on the connection between food tourism and rural territories by exploring its potential through a systematic literature review on this untapped topic. Based on 73 articles focusing on those connections, the paper reviews and further explores what is already known on the topic, examining the different research methodologies and approaches used, as well as the dimensions analysed and results obtained. Research on the links between food tourism and rural territories seems to be geographically marked and particularly relevant in Southern European countries (such as Spain and Italy), as well as in North America (mainly the USA). Impacts on local development, together with production and commercialization strategies, are the main dimensions analysed by the articles, revealing indeed some of the potential virtuous bonds deriving from the connection between tourism, food and rural territories.

Keywords: food tourism; rural development; rural territories; systematic literature review

Resumo: Ainda que os estudos sobre alimentação e turismo tenham ganho terreno no âmbito da investigação em turismo, especialmente ao longo da última década, as ligações entre turismo gastronómico e os territórios rurais constituem um tópico relativamente pouco explorado. Isto é particularmente significativo no contexto de um crescente reconhecimento de que os produtos alimentares constituem um fator de distinção dos destinos turísticos rurais, ao mesmo tempo permitindo promover heranças e tradições específicas, assim como contribuir para o desenvolvimento local. O presente artigo tem por objetivo desvendar as relações entre turismo, alimentação e territórios rurais, explorando o seu potencial através de uma revisão sistemática da literatura. Com base em 73 artigos centrados naquelas relações, o artigo revê e explora o conhecimento que tem sido produzido sobre este tópico, examinando as diferentes metodologias e abordagens utilizadas, assim como as dimensões analisadas e os resultados obtidos. A investigação que tem sido conduzida sobre as relações entre alimentação, turismo e territórios rurais parece ser geograficamente marcada e particularmente relevante nos países do Sul da Europa (como a Espanha e a Itália), bem como na América do Norte (especialmente nos Estados Unidos). Os impactos no desenvolvimento rural, em conjunto com as estratégias de produção e comercialização dos produtos e experiências, são as principais dimensões analisadas nos artigos recolhidos, revelando de facto alguns aspetos das potenciais ligações virtuosas que decorrem das relações entre turismo, alimentação e territórios rurais.

Palavras-chave: alimentação; revisão sistemática da literatura; territórios rurais; turismo e alimentação

\section{Highlights:}

- This is the first systematic review on the connections between food tourism and rural territories

- The prominence of Southern Europe regarding the literature on the connections between food tourism and rural territories is revealed by the systematic review

- The impacts on local development, production and commercialization strategies, and tourism demand-related issues are the main dimensions analysed by the papers reviewed 
- A geographically marked use of different food tourism perspectives, also representing a diversity of approaches and topics covered by the papers reviewed is evinced

- The connections between food tourism and rural territories are manifold and complex.

\section{Introduction}

Although the relationship between food and tourism has been salient within tourism studies for more than three decades, only recently has its prominence increased within a variety of disciplines (as geography, cultural studies, sociology and anthropology) (Cohen \& Avieli, 2004; Ellis et al., 2018; Everett \& Aitchison, 2008). This quantitative increase was accompanied by a qualitative change in terms of diversification and broadening of the theoretical approaches and conceptualizations. This increased attention went alongside a growing interest from institutions as UNESCO, OECD and UNWTO that converged on valuing the relationship between food and culture, stressing the potential impact of food and gastronomy in territorial dynamics and the need to promote related policies.

Food tourism has been generally defined as the "visitation to primary and secondary food producers, food festivals, restaurants and specific locations for which food tasting and/or experiencing the attributes of specialist food production region are the primary motivating factor for travel" (Hall \& Sharples, 2003: 10). Considering this general definition, Henderson (2009), in the first attempt to review the contribution of food to tourism, tried to identify the main challenges and future research directions in the field. Nine years later, Ellis et al. (2018) undertook a different literature review on the topic, adopting a more holistic, assessment-based approach to the existence of a critical gap in understanding food tourism as a whole, especially concerning its definition, approaches, themes and conceptualizations. This is evidenced by the interchangeability of the terms 'food tourism', 'culinary tourism', 'gastronomic tourism' and, also, to a lesser extent, 'gourmet tourism' and 'tasting tourism' (Ellis et al., 2018; Horng \& Tsai, 2012; Pavlidis \& Markantonatou, 2020).

According to the findings of the literature review performed by Ellis et al. (2018), the use of these different terms, especially the first three mentioned above, corresponds to equally different perspectives. The authors conclude that 'culinary tourism' is the most used term and that it designates an intrinsic connection between food and culture, with food being a medium to enhance tourists' cultural experiences (Horng and Tsai, 2012). 'Gastronomic tourism' appears to be used far less in the literature than 'culinary tourism' or 'food tourism' as suggested by Elis et al.'s (2018) findings. In any case, 'gastronomic tourism' generally refers to the original character of a dish as well as to its links to a specific provenance and location (Green \& Dougherty, 2008). The difference between this and 'culinary tourism', as Ellis et al. (2018) present it, lies in the greater focus on the tourists' cultural experience of the latter and the host-driven focus of 'gastronomic tourism', including the place of food in the host culture (Pavlidis \& Markantonatou, 2020). The second, more frequently used term - 'food tourism' - refers firstly to the broader definition of the relationship between tourism and food, as in Hall and Sharples's (2003) statement above. Secondly, the term refers to a more physical and sensorial experience of local food (e.g., Cohen \& Avieli, 2004). Interestingly, as put forward by Rachão et al. (2019), the use of these terms appears to be geographically anchored. While the literature from Australia and New Zealand seems to privilege 'food tourism', studies from the United States and Canada prefer the term 'culinary tourism', with 'gastronomic (or gastronomy) tourism' being more frequently used by European literature.

Regardless of the term used to coin the interrelation between food and tourism, culture and cultural experiences appear to be a keystone, paving the way for a 'cultural turn' (Ellis et al., 2018; Everett, 2012). The engagement of tourists with local food products in different settings has started to draw attention from research regarding not only the impact on specific territories (such as rural ones) (Everett \& Aitchison, 2008) but also the symbolic approach to food. In fact, as Cohen and Avieli (2004) and, more recently, Ellis et al. (2018) pointed out, food tourism studies are increasingly adopting an anthropological and sociological perspective following the seminal work of Bessière (1998) on the more than nutritious character of food. Its territorially anchored 
symbolic and cultural characteristics are emphasizing, contributing to opening the research area to a number of studies dealing with the immaterial dimensions of food and its touristic value. Hence, being acquainted with food products, gastronomy and cuisine of a particular territory is a fundamental part of the process of knowing its culture and lifestyle (Figueiredo, 2021; Pavlidis \& Markantonatou, 2020). The territory, as the biophysical and sociocultural context for food production, emerges as a key notion, since food is embedded with its specific character, knowhow, cultural values and practices (Figueiredo, 2021). In this sense, it became evident that rural traditional foodstuffs, from agricultural practices to culinary ones, are strongly connected to rural tourism activities and experiences and hold a key position as pull factors to a particular rural destination (du Rand \& Heath, 2006; Horng \& Tsai, 2012; Rachão et al., 2019).

Sims (2009) and Renko et al. (2010) precisely pointed out the positive consequences for rural territories and destinations deriving from rural provenance food on offer for tourists in economic, cultural and environmental sustainability terms. Despite this recognition, the analysis of the particular nature of the connections between food tourism and rural territories remains relatively underexplored. As it will be further discussed in the subsequent sections, the majority of the till now limited research conducted about food tourism and rural territories, examine the role of food heritage and experiences in fostering rural development (especially emphasizing the management and marketing dimensions), as rural territories are the most common locations for food production and food-related products and undertaking of activities. The focus on rural territories which the present paper adopts allows a better discussion of the potential of food to be used by tourism industries, to feature in a wide variety of cultural and touristic-based activities and, also, to represent an increasing part of tourist spending in rural areas. As such, food does not only convey important cultural functions and values but can also foster social, environmental, territorial and economic cohesion in rural contexts, as well as contributing to sustaining cultural heritage and food diversity and helping the revival of the sociocultural fabrics of rural areas.

Within this context, the main objective of this paper is to provide a systematic literature review on the connection between food tourism and rural territories as, despite its pertinence, it remains an underexplored subject. Based on 73 papers, the systematic review presented here aims to fill this gap and contribute to guiding further research by mapping the theoretical and methodological patterns featuring this research area. The geographical contexts of research, researched subjects of the articles considered as well as the main dimensions emphasized in the relationship between food tourism and rural territories are identified. The systematic literature review presented here aims to contribute to the debate on that relationship by shedding some light on the dimensions analysed, existing gaps and further research avenues.

\section{Methodology}

To identify empirical and theoretical contributions for the topic at hand, the present study adopted a systematic literature review approach, following the suggested guidelines by Kitchenham (2004), which is found to provide comprehensive and replicable data through the synthesis of relevant information collected across several domains of expertise. Despite the diverse methodologies that may be employed to conduct systematic literature reviews (Centobelli and Ndou, 2019), in this paper, a two-step protocol was used (e.g., Eusébio et al., 2020; Rachão et al, 2019; Xiao \& Watson, 2019). Firstly, a set of criteria were defined to select the articles to be reviewed, following the PRISMA ${ }^{2}$ guidelines and steps and secondly, content and thematic analysis of those articles were conducted.

\section{Selection of articles}

The search for relevant literature (Fig. 1) was limited to peer-reviewed journals listed and available on Scopus. This database was chosen because, in addition to being the most commonly used scholar database to conduct systematic literature reviews, it has broader and more complete 2 Preferred Reporting Items for Systematic Reviews and Meta-analyses - http://prisma-
statement.org/prismastatement/flowdiagram.aspx 
overall coverage of academic journals (over 20000 peer-reviewed ones) (Centobelli and Ndou, 2019). The search on Scopus took place on November 2019 using the following Boolean search codes - ('Gourmet tourism' or 'Food tourism' or 'Culinary tourism' or 'Gastronomic tourism') in the articles' title, abstract and keywords, without any other limitation. This search returned 511 records, with the first paper being published in 1985. As 2013 represents a turning point regarding a significant increase in the number of articles on the topic, together with the small number of papers published between the previous 28 years $(27.8 \%$ of the initial number of articles found), it was decided to analyse just those published in the last six years. Following that decision, the first screening reduced the number to 369 articles published between 2013 and $2019(72.2 \%$ of the initial number of articles found), which allows the recent evolution of the topic to be traced.

The 369 articles were then subjected to a manual screening of titles and abstracts to assess their relevance according to the predefined inclusion and exclusion criteria. The main criterion for inclusion was that the articles explicitly connect food tourism to rural territories. In the cases in which the titles and abstracts were not conclusive, the whole article was screened to assess its suitability for inclusion. Conversely, articles without an abstract, reporting overviews and reviews, systematic or otherwise, were excluded. Articles written in a language not understood by the authors (i.e. languages other than Portuguese, English, French, Catalan, Spanish and Italian) were also excluded. Both theoretical and empirical studies were included. After this manual screening, 73 articles were selected to be further analysed.

\section{Analysis of articles}

The 73 articles were analysed in three stages. Firstly, a descriptive analysis was conducted focusing on the following aspects:

- Distribution of over time;

- Type of articles and language;

- Distribution by journal and scientific field;

- Distribution by geographical settings.

Secondly, the articles' titles, abstracts and keywords were subjected to content analysis, using NVivo 12 software, to identify the most used terms in this research area. Finally, as both theoretical and empirical studies were retrieved, a thematic analysis of the empirical papers (68) was performed to identify:

- The research methods used for data collection and analysis;

- The dimensions analysed related to tourism demand, food production and commercialization and impacts on local development.

Thematic analysis comprised of the identification of the articles' main methodological and conceptual features and was based firstly on a quantitative analysis. A coding frame was created containing a set of features (such as specific data collection and analysis methodologies, countries of case studies, methodological approaches, samples used) to register their corresponding presence (1) or absence (0) in the articles collected. Following this procedure, a combination of quantitative and qualitative thematic analysis was conducted to identify the articles' main focus and dimensions. Three main themes (demand, food production and commercialization and impacts on local development) emerged considering the main systematic literature review objectives, the value chain of tourism (mainly demand, production and commercialization) as well as literature on the topic, especially regarding impacts on local development deriving from tourism (e.g., Renko et al., 2010; Sims, 2009; Everett and Aitchison, 2010) and examination of the content of the selected articles. 


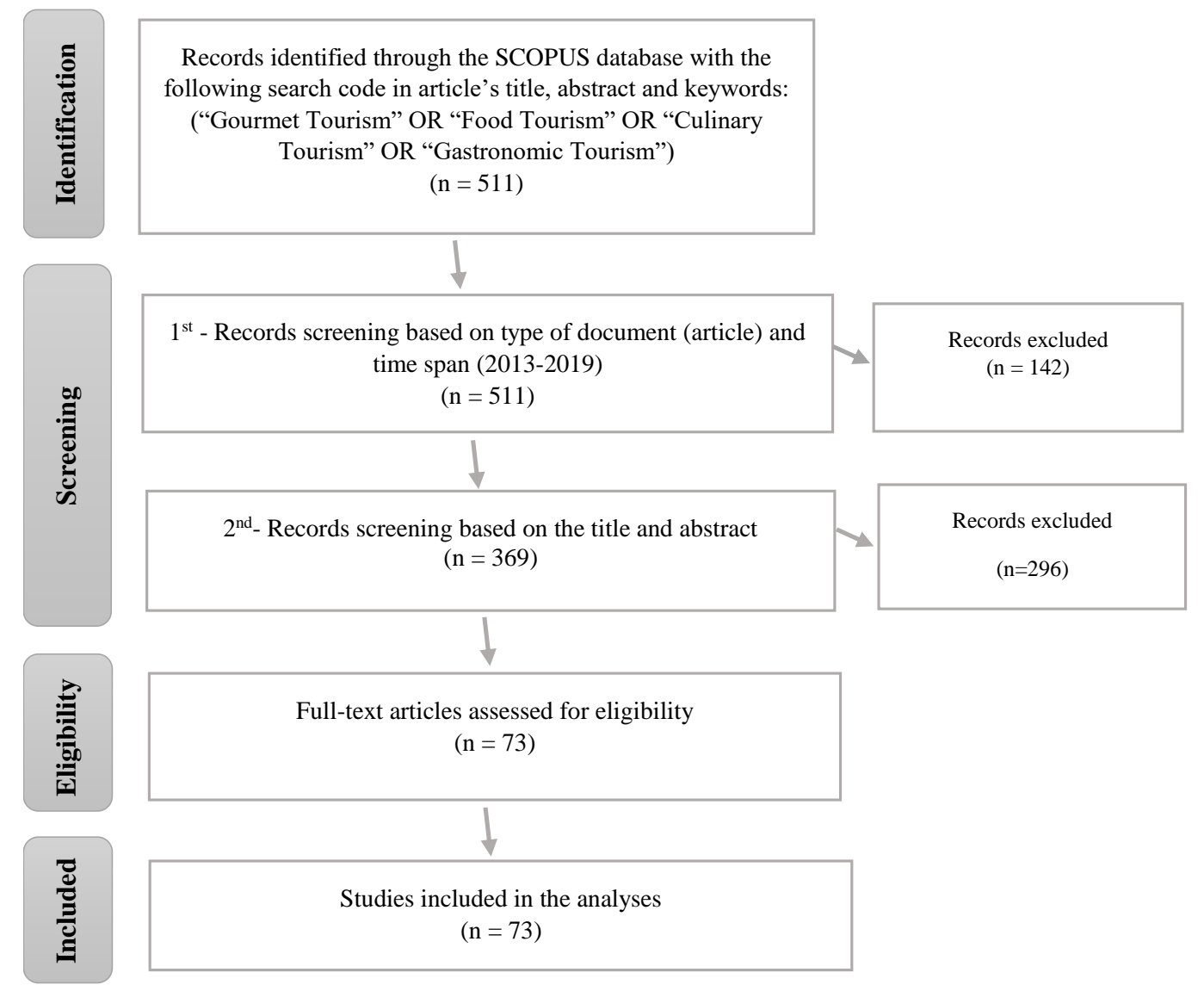

Fig 1. PRISMA flow diagram of the article selection process. Source: self-elaboration

\section{Results}

\section{Distribution over time, type of papers and language}

Despite the progressive increase in the number of studies dealing with food and tourism since the beginning of the 2000s (Ellis et al., 2018; Everett and Aitchison, 2008), the number of articles focusing on the connections between food tourism and rural territories represents just $19.7 \%$ of the total of articles initially collected on food and tourism, which demonstrates the underexplored nature of the topic. However, during the last six years, the publications on the topic showed a relatively consistent growing tendency until 2016-2017 (Fig. 2). In 2018 there were substantially less publications with a significant new increase in 2019.

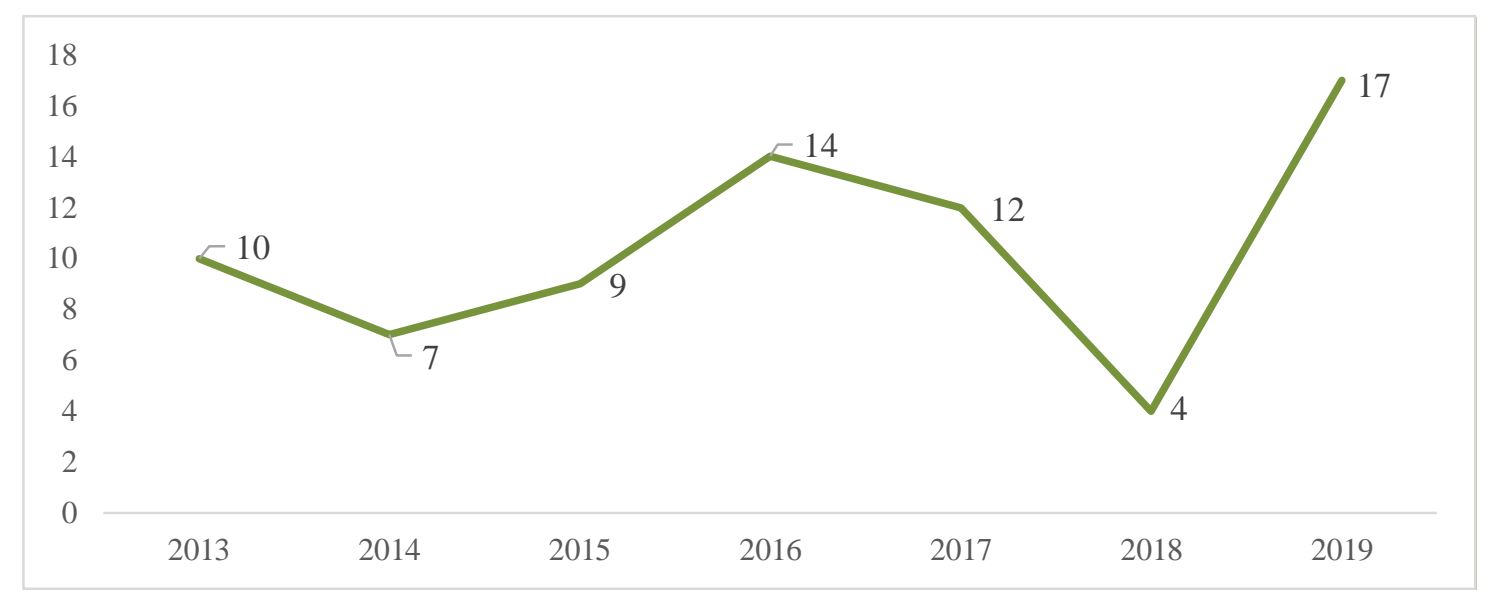

Fig 2. Number of articles by year. Source: self-elaboration 
From the 73 articles collected, 68 are of an empirical nature and five are mainly theoretical. Regarding the language, and not surprisingly given the use of the Scopus database (in which English-language papers are largely predominant, as pointed out by Vera-Baceta et al., 2019) $67(89.3 \%)$ articles are written in English, 5 (6.8\%) in Spanish and $1(1.3 \%)$ in Catalan.

\section{Distribution by journal and scientific fields}

The articles were published in a variety of journals and subject areas revealing their multidisciplinary character, as also pointed out by Ellis et al. (2018) and Everett and Aitchison (2008) regarding food tourism in general. In fact, the journals that published these articles are often classified in more than one subject area (on Scopus), again indicating the interdisciplinary and multidisciplinary character of research on food, tourism and rural territories. Due to the great variety of the journals' scientific areas, articles were grouped according to the most related scientific field, usually evidenced by the title of the journal. Even though, as shown in Figure 3, there is a higher prevalence of articles in journals from the fields of 'tourism and hospitality' (52\%), there is also a significant percentage of articles published in 'geography' (16.4\%), 'environmental science' $(9.5 \%)$ and 'food science' (8.2\%). The remaining articles are distributed across journals of other social sciences disciplines, focusing on different fields of research, such as sociology, anthropology and psychology. Despite the predominance of tourism and hospitality-related journals, when looking at the specific journals 'Sustainability' $(n=6)$ is the journal with more published articles, followed by the 'British Food Journal' $(n=4)$, which again highlights the interest and interdisciplinary character of the topic.

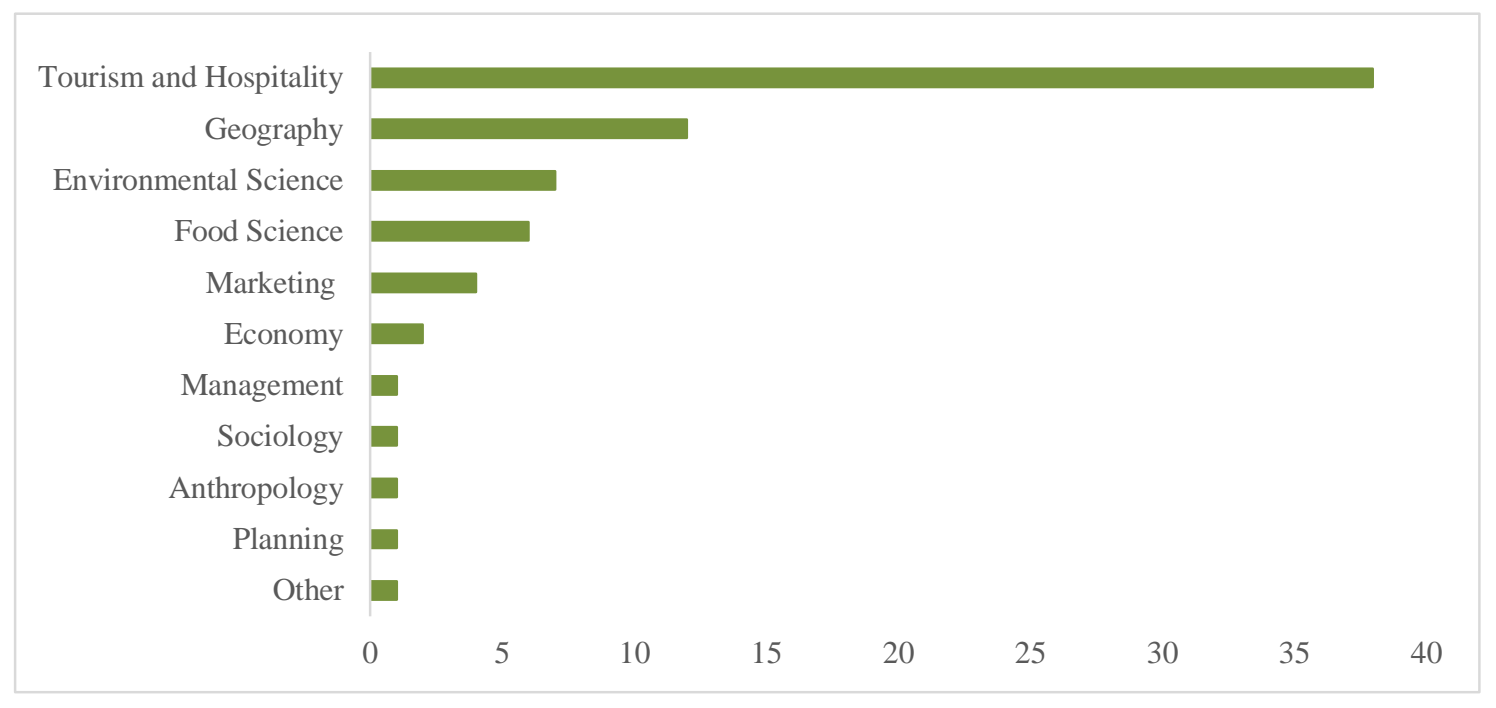

Fig 3. Number of articles by main scientific area. Source: self-elaboration

\section{Distribution by geographical settings}

Notwithstanding the worldwide spatial distribution of the articles, Europe is clearly predominant $(50.6 \%)$, followed by Asia (17.8\%) and North America (13.6\%). Within Europe (Fig. 4), Spain $(20.8 \%)$ and Italy (10.4\%) clearly take the lead, indicating that the connection between food, tourism and rural territories seems to be a more relevant research topic of Southern European interest, possibly connected to common paths of rural change and restructuring. Within Asia, China, Japan and India stand out as the countries where most studies have been conducted. As for North America, the USA takes the lead, and is also the second country worldwide (after Spain) with the most studies. 


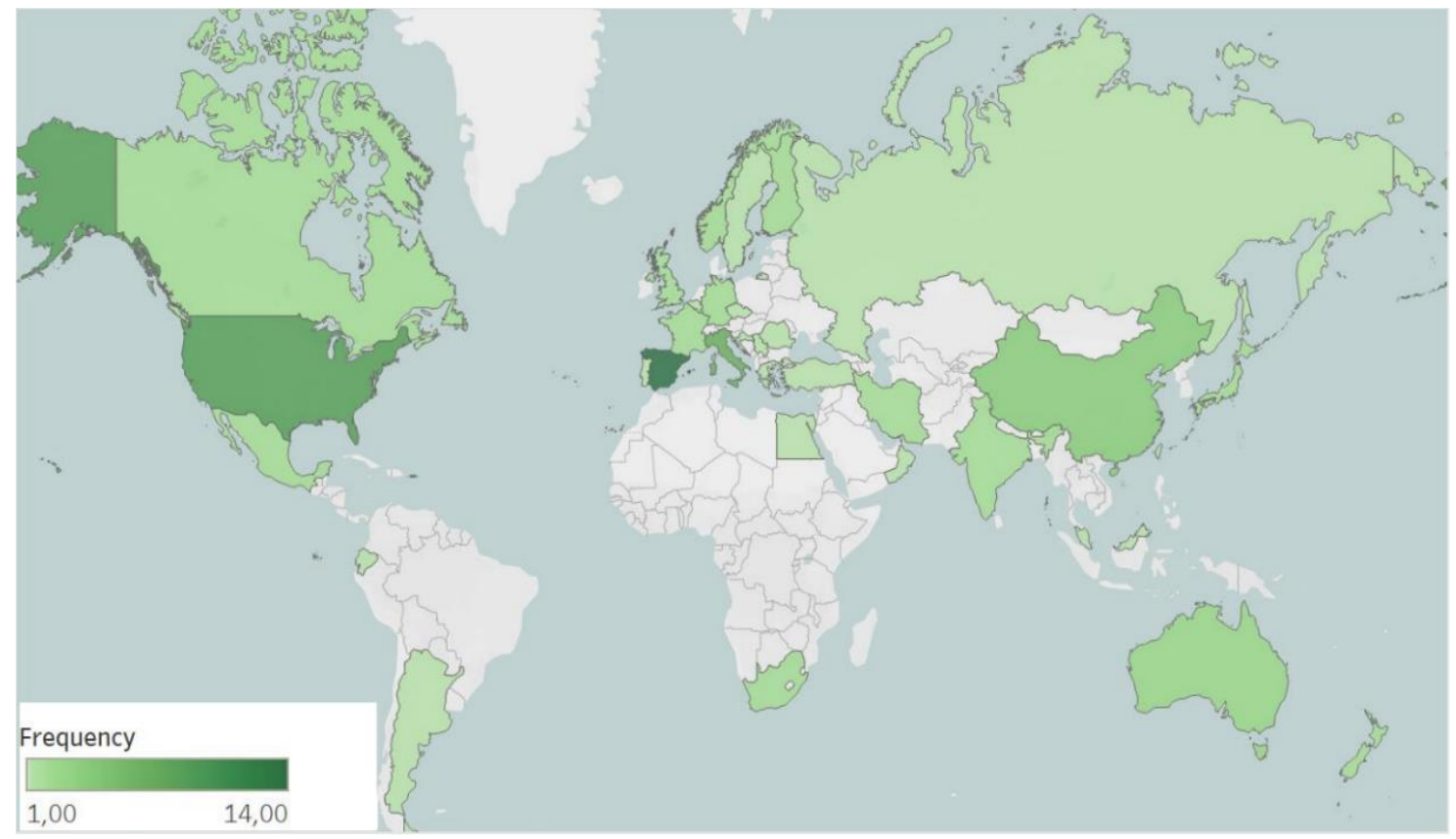

Fig 4. Distribution of articles by geographical setting-countries. Source: self-elaboration

Six articles were conducted in more than one country, five of them considering countries within the same continent and one examining countries from different continents. $27.9 \%$ of the 68 empirical articles examine only rural territories, while the great majority $(67.6 \%)$ involved the analysis of rural and urban territories or even geographical contexts on urban fringes (here considered mixed or intermediate areas). $4 . \%$ of the articles examined sites located on islands.

\section{Research Methods}

Only five articles are of a theoretical character (Allen, 2017; Fusté-Forné, 2015; Gyimóthy, 2017; Mnguni \& Giampiccoli, 2015; Sidali et al., 2013). In this section, the methods used in the remaining 68 (empirical) articles are analysed, as it was considered useful to inform and guide future research on this field.

\section{Data collection methods}

Figure 5 shows a relative predominance of qualitative methodologies for data collection, although quantitative methodologies are also in evidence. Eleven articles use a mix of both methodologies, combining, for example, interviews, focus groups and questionnaires or questionnaires and participant observation.

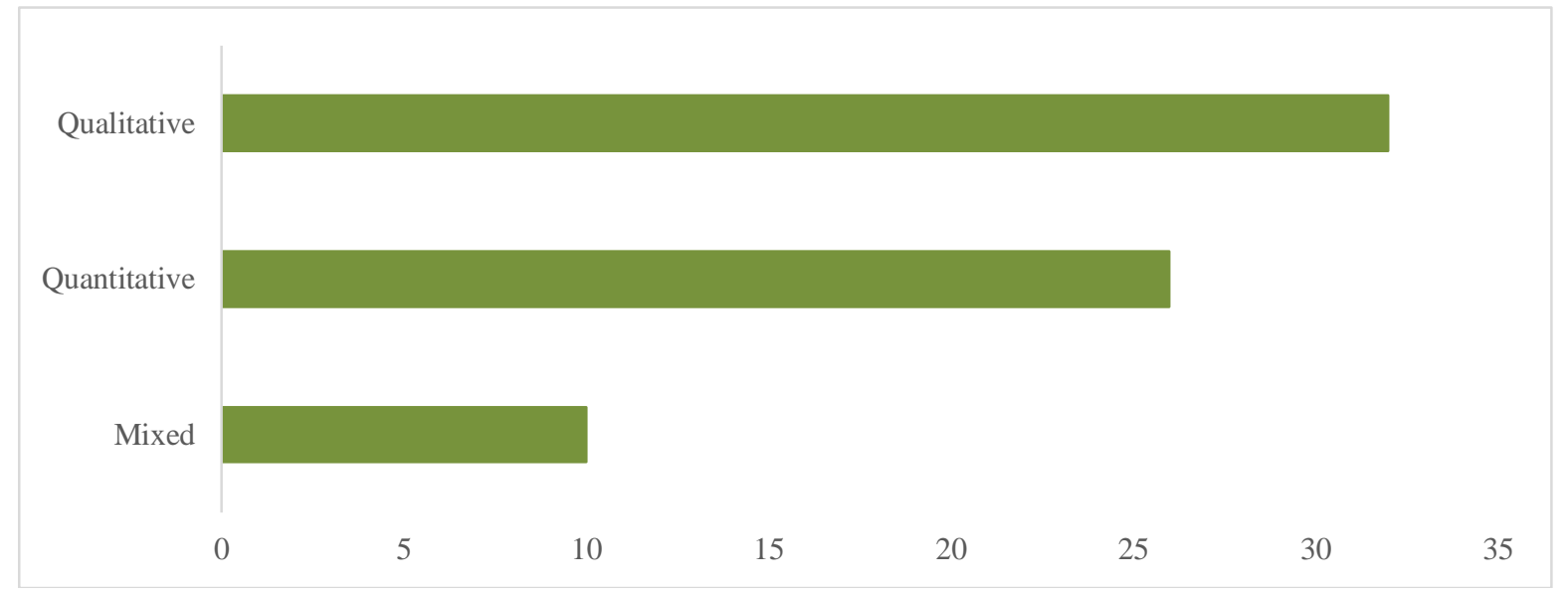

Fig 5. Data collection methods used in the articles. Source: self-elaboration 
On a related note, and following the salience of data collection qualitative methods, Table 1 shows that the interview is the most common technique employed to collect primary data (35.3\%), followed by participant and/or direct observation (23.5\%), mainly to collect information regarding local inhabitants. These include a wide array of actors, for instance, mushroom pickers (FustéForné, 2019), traditional female cookers (Ardren, 2018; Matta, 2019), smallholder farmers (Liu, et al., 2017) and food producers (as in Guan et al., 2019; Londono \& Palomeque, 2017; Mei et al., 2017; Pavia et al., 2014; Spilková \& Fialová, 2013).

On the quantitative side, the use of questionnaires stands out, with $50 \%$ of the articles using this tool (Tab. 1), especially to collect information from tourists and tourism industry agents. In several articles the questionnaire is combined with other, often qualitative types of techniques, as the above examples illustrate.

Table 1. Type of data, collection method, sources and samples. Source: self-elaboration

\begin{tabular}{|c|c|c|}
\hline Type of data & $\begin{array}{l}\text { Type of data } \\
\text { collection } \\
\text { method/sources } \\
\text { and sample }\end{array}$ & Articles \\
\hline \multirow[t]{3}{*}{ Primary data } & $\begin{array}{l}\text { Questionnaire } \\
\text { Residents } \\
\text { Tourists } \\
\text { Tourism Industry } \\
\text { Agents }\end{array}$ & $\begin{array}{l}\text { Campón-Cerro et al. (2017), Mei, et al. (2017), Londono \& Palomeque } \\
\text { (2017), Murray \& Kline (2015), Pavia et al. (2014), Spilková \& Fialová } \\
\text { (2013) } \\
\text { Anderson, et al. (2016), Bjork \& Kauppinen-Raisanen (2014), Bressan } \\
\text { \& Alonso (2013), Busby et al. (2013), De la Torre et al. (2014), } \\
\text { Dimitrovski (2016), Folgado-Fernandez et al. (2017), Garner \& Ayala } \\
\text { (2019), Hernandez-Mogollón et al. (2015), Jimenez et al. (2019), Kim } \\
\text { (2016), Kim et al. (2015), Lai et al. (2019), Morales et al. (2015), } \\
\text { Murray \& Kline (2015), Popp \& McCole (2016), Sohn \& Yuan (2013), } \\
\text { Testa et al. (2019) } \\
\text { Campón-Cerro et al. (2017), Casalegno et al. (2019), De la Torre et al. } \\
\text { (2014), De la Torre et al. (2016), Enzenbacher (2019), Folgado- } \\
\text { Fernandez et al. (2017), Garibaldi \& Pozzi (2016), Getz \& Robinson } \\
\text { (2014), Hernandez-Mogollón et al. (2015), Hjalager \& Johansen (2013), } \\
\text { Kim et al. (2015), López-Guzmán (2016), Prat Forga \& Valiente (2014), } \\
\text { Sidali et al. (2017), Spilková \& Fialová (2013), Thomas Lane et al. } \\
\text { (2016), Updhyhay \& Sharma (2014) }\end{array}$ \\
\hline & $\begin{array}{l}\text { Interviews } \\
\text { Residents } \\
\text { Tourists } \\
\text { Tourism Industry } \\
\text { Agents }\end{array}$ & $\begin{array}{l}\text { Ardren (2018), de St. Maurice (2017), Fusté-Furné (2019), Guan et al. } \\
\text { (2019), Liu et al. (2017), Matta (2019), Mei et al. (2017), Pavia et al. } \\
\text { (2014), Robinson \& Bingjie (2019), Sidali et al. (2016), Teixeira \& } \\
\text { Ribeiro (2013), Yang et al. (2019) } \\
\text { De la Torre et al. (2016), de St. Maurice (2017), Enzenbacher (2019), } \\
\text { Kunasegaran et al. (2019), Mei et al. (2017), Metaxas \& Karagiannis } \\
\text { (2016), Ottenbacher \& Harrington (2013) Sidali et al. (2016), Thomas } \\
\text { Lane et al. (2016) }\end{array}$ \\
\hline & $\begin{array}{l}\text { Focus groups } \\
\text { Residents }\end{array}$ & Pavia et al. (2014) \\
\hline
\end{tabular}




\begin{tabular}{|c|c|c|}
\hline & $\begin{array}{l}\text { Tourists } \\
\text { Industry Tourism } \\
\text { Agents }\end{array}$ & $\begin{array}{l}\text { Anderson et al. (2016), Dimitrovski (2016), Kim (2016), Omar et al. } \\
\text { (2019), Pavia et al. (2014) } \\
\text { Kim (2016), Sotiriadis (2013) }\end{array}$ \\
\hline & $\begin{array}{l}\text { Experiments } \\
\text { Residents } \\
\text { Tourists }\end{array}$ & $\begin{array}{l}\text { Lenglet \& Giannelloni (2016) } \\
\text { Lenglet \& Giannelloni (2016) }\end{array}$ \\
\hline & 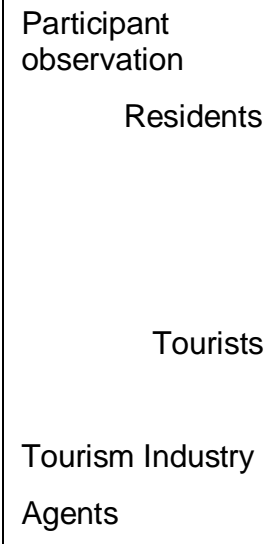 & $\begin{array}{l}\text { de Jong \& Varley, (2018), de St. Maurice (2017), Fusté-Forné (2019), } \\
\text { Guan et al. (2019), Kim \& Ellis (2015), Londono \& Palomeque (2017), } \\
\text { Liu et al. (2018), Sidali et al. (2016), Robinson \& Bingjie (2019), Teixeira } \\
\text { \& Ribeiro (2013) } \\
\text { Bertella (2014), Guan et al. (2019), Kim \& Iwashita (2016) } \\
\text { Enzenbacher (2019), Guan et al. (2019), Lee et al. (2015), Londono \& } \\
\text { Palomeque (2017), Liu et al. (2017), Yang et al. (2019) }\end{array}$ \\
\hline & $\begin{array}{l}\text { Document } \\
\text { analysis }\end{array}$ & $\begin{array}{l}\text { Broadway (2017), De la Torre et al. (2016), Doganer, (2017), } \\
\text { Enzenbacher, (2019), Fusté-Forné (2016), Fusté-Forné (2018), lizuka } \\
\& \text { Kikuchi (2016), Lee et al. (2015), Liu et al. (2017), Mei et al. (2017), } \\
\text { Mohamed et al. (2019), Okumus et al. (2013), Popp \& McCole (2016), } \\
\text { Silkes et al. (2013), Yang et al. (2019) }\end{array}$ \\
\hline Secondary data & $\begin{array}{l}\text { Document } \\
\text { analysis }\end{array}$ & $\begin{array}{l}\text { de Salvo et al. (2013), Diaconescu et al. (2016), Fusté-Forné (2019), } \\
\text { Kim \& Ellis (2015), Robinson \& Bingjie (2019), Sidali et al. (2017), } \\
\text { Teixeira \& Ribeiro (2013), Yang et al. (2019) }\end{array}$ \\
\hline
\end{tabular}

It is not uncommon for articles to analyse diverse actors and stakeholders, such as Ardren (2018) who addresses both residents and visitors or Londono and Palomeque (2017) who analyse both residents (farmers mainly) and agents of the tourism industry (such as restaurant owners and distributors). Guan et al. (2019), on a different note, explore the views of local producers, tourists and tourism industry agents on food heritagization processes and their impacts on rural development. The diversity of stakeholders analysed by the articles demonstrates the variety of actors and agents involved in food tourism in rural areas. However, there is a greater focus on tourists and tourism industries than on residents (including farmers and other food producers), indicating a somewhat larger emphasis on the tourists' experiences both from the demand and the offer points of view.

Document analysis is conducted in fifteen articles, mainly to collect primary data and often is combined with other collection techniques, mostly of a qualitative nature. Articles seldom use secondary data to analyse the connections between food tourism and rural territories (11.7\%) revealing that, in this field, empirical research is tailored specifically to meet the aims and requirements of a particular investigation. 


\section{Data analysis methods}

Despite the relevance of qualitative techniques in collecting data, methods used in data analysis are mainly of a quantitative nature (Table 2). Only a few articles combined both qualitative and quantitative methods for data analysis. As for the most frequent techniques for qualitative data analysis, a substantial number use content analysis, either performed manually or with software (like NVivo or MAXQDA). Thematic analysis and narrative analysis are also employed in a number of articles.

Tab 2. Data analysis methods. Source: self-elaboration

\begin{tabular}{|c|c|c|}
\hline Type of methods & Description of the method & Articles \\
\hline \multirow[t]{5}{*}{ Qualitative } & Content analysis & 20 \\
\hline & Thematic analysis & 7 \\
\hline & Narrative analysis & 6 \\
\hline & Discourse analysis & 2 \\
\hline & Qualitative comparative analysis (QCA) & 1 \\
\hline \multirow[t]{10}{*}{ Quantitative } & Descriptive statistics & 34 \\
\hline & Reliability analysis (Cronbach's alpha) & 10 \\
\hline & Exploratory factor analyses and confirmatory factor analyses & 8 \\
\hline & Correlations & 6 \\
\hline & Regression analysis & 5 \\
\hline & Structural equation models & 4 \\
\hline & ANOVA, multivariate analysis of variance & 4 \\
\hline & ARIMA/SARIMA Modelling time-series & 2 \\
\hline & Cluster analysis & 2 \\
\hline & T-tests & 1 \\
\hline
\end{tabular}

The articles use a wide variety of quantitative techniques, with descriptive statistics being the most frequent on its own, or used before performing bivariate and multivariate statistical analysis. Amongst these, exploratory factor analysis and correlation tests seem to be the most commonly used to explore data properties and co-relationships. About $10 \%$ of the studies use regression models and structural equation models to examine causal relationships between the variables under analysis. It is worth noting that ten articles do not refer to the specific analysis techniques used.

\section{Most frequently used terms}

A word frequency query using NVivo 12 software was performed separately on the title, abstracts and keywords of all 73 articles to explore the most salient themes and terms used. Besides the grammatical words (e.g., prepositions, conjunctions) that do not add much to the analysed content (and hence were excluded by default), the four expressions used in the initial search protocol (described in section 2) were also excluded from the queries: 'gourmet tourism'; 'food tourism'; 'culinary tourism' and 'gastronomic tourism'.

After applying the aforementioned filters, the results indicate 182 words for titles, 134 for keywords and 502 for abstracts. When comparing the salience of the words used (Fig. 6) 'development', 'locals', 'cultural', 'destination', 'marketing' and 'sustainable' stand out across the three lists, although with slight differences in terms of salience, reflecting the common topics between the articles considered in this review. 
From the evidence provided by the word frequency query conducted on the titles, keywords and abstracts of the selected articles, it can be seen that food tourism is often related to rural sustainable development, cultural patrimony and heritage and the tourists' experiences with food locally produced and/or prepared in the destination, as well as to the marketing and promotion of food products.

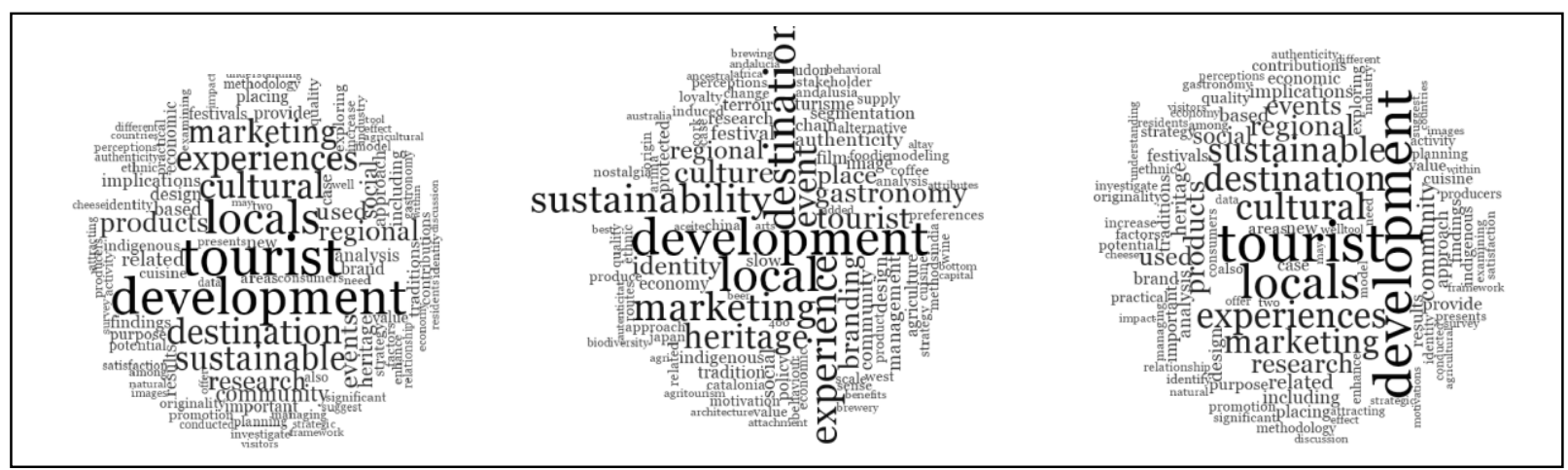

Fig 6. Tag clouds representing the word frequency in the articles' titles, keywords and abstracts. Source: self-elaboration

\section{Dimensions analysed}

In terms of the conceptual approaches taken by the articles, the majority (32.3\%) are focused on food tourism, $27.9 \%$ refer to gastronomy tourism and $25 \%$ to culinary (and cuisine-related) tourism. As in the study by Rachão et al. (2019), some geographic differences may be observed. While European-based studies tend to adopt a gastronomy perspective, the literature from the United States more frequently embrace a culinary tourism approach. Food tourism is adopted as a more general perspective and its use is common to several of the examined studies, independently of its geographic origin and focus.

Three main dimensions were identified through content and thematic analysis: impacts on local development (the most analysed dimension - 44 articles); food production and commercialization (39) and demand (30). It is worth noting that the majority of the articles explore more than one dimension, combining, for example, analysis of the production and commercialization or demand with the examination of the impacts on local development. This intersection of dimensions suggests that the connections between food tourism and rural territories are manifold. Although not considering exactly the same dimensions, this is in line with Ellis et al. (2018) and, to a lesser extent, with Henderson (2009).

\section{The demand dimension}

The demand dimension includes variables related to motivations, experiences and factors influencing rural food consumption. These variables are very often addressed together in the articles. The analysis of motivations is present in all 30 articles analysed within the demand dimension and includes references to the push and pull factors driving tourists to embark on a visit or events related to food, in line with the findings of du Rand and Heath (2006), Horng and Tsai (2012) and Rachão et al. (2019). In this regard, articles emphasize different aspects such as specific features of destination image, as hospitality (Shtapit, 2017); environment (Sidali et al., 2017); landscape (Anderson et al., 2016); quality of life (Testa et al., 2019); loyalty and visiting habits (Folgado-Fernandez et al., 2017); food quality and authenticity (Bjork \& KauppinenRaisanen, 2014; Casalegno et al., 2019; Dimitrovski, 2016; Lenglet \& Giannelloni, 2016); and culture and tradition (Folgado-Fernandez et al., 2017; lizuka \& Kikuchi, 2016). The emphasis on these aspects demonstrates the relevance of the sociocultural and biophysical features of rural territories in food tourism, as also pointed out by Bessière (1998) and Figueiredo (2021).

Experiences are analysed by 29 articles dealing with the demand dimension, again emphasizing the pronounced intertwining between a given gastronomic offer of a region and other symbolic cultural attributes. There is a strong liaison between the factors underlying particular tourism choices and the experiences offered and lived, as evidenced by the fact that motivations and 
experiences are mentioned together in the large majority of articles (29 out of 30 ). This can be seen, for example, in the drive to partake in a regional identity through food while forging a connection with the producer (Garner \& Ayala, 2019), to visit cultivation sites (Casalegno et al., 2019) or to taste traditional food with historical connections (Updhyhay \& Sharma, 2014). This shares perspectives that are in line not only with the cultural turn identified by Everett and Aitchison (2008), but also with the observations regarding the cultural symbolic approaches to foodstuffs, in line with Bessière (1998). Furthermore, the analysis of experiences with food includes the study of specific - and custom-designed - events to promote memorable food experiences (as in Dimitrovski, 2016; Folgado-Fernandez et al., 2017; Kim et al., 2015; Shtapit, 2017) and visits to specific terroirs or food routes (Hernandez-Mogollón et al., 2015; Jimenez, 2019; De La Torre et al., 2019) as well as product-based tourism such as that of olive oil (CampónCerro et al., 2017; López-Guzmán et al., 2016; Morales et al., 2015). They also include farmers' markets (Garner \& Ayala, 2019), community-based initiatives (Matta, 2019) and connections with other mediums such as cinema (Busby et al., 2013). On a different note, Campón-Cerro et al. (2017), Kim and Iwashita (2016) as well as Murray and Kline (2015) also advance the role of residents (and their interactions with tourists) for successful tourism-related initiatives, examining a less studied - albeit important to the tourists' experiences, thus needing to be further explored - type of stakeholders within food tourism literature - the local inhabitants.

Both the examination of motivations and experiences often include the analysis of the factors that influence consumption. In fact, 28 out of 30 articles dealing with the demand dimension analyse these factors. In this regard, both travel features (such as hospitality, services, comfort, entertainment) and food product features (food attributes like taste and smell, authenticity, novelty, tradition) together with consumer features (gender, age, nationality, status, income and personality characteristics) are often emphasized by the articles (as in Anderson et al. (2016) and Kim (2016) regarding specific events and settings; Kunasegaran and Rasoolimanesh (2019) systematizing predictors of higher consumption; Lenglet and Giannelloni (2016) referring to terroir products and testing how different types of local and non-local consumers would assess it; Morales et al. (2015) assessing the surrounding culture of olive oil; Bjork \& Kauppinen-Raisanen (2014) analysing the consideration by consumers of traditional processes and ways of production as part of the food experience).

\section{The food production and commercialization dimension}

The 39 articles alluding to food production and commercialization highlight dimensions like marketing strategies (38), also in line with the findings of Ellis et al. (2018). This is followed by the exploration of production-commercialization networks and the origin of products, equally present in the majority of the articles (36) and by food production processes (32).

The depth in which these articles explore these dimensions differs significantly. Regarding marketing strategies, some articles analyse this dimension extensively and propose strategic plans, networks and synergies amongst stakeholders to foster food tourism (as in Ottenbacher \& Harrington, (2013), which lays out the components of a successful culinary tourism campaign, or Liu et al. (2017), who propose a detailed conceptual framework to foster agri-food tourism using an eco-innovation strategy). The most salient aspects within this dimension are place and regional branding, as well as foodscapes marked by the savoir faire and traditional character of production. Regarding the first aspect, for example, Thomas Lane et al. (2016), referring to Wales, and Broadway (2017, referring to West Cork, Ireland, investigate the regional branding through food and drink that emphasizes rural imagery and food heritages. The importance of regional producers with certified brands is also explored within this dimension (as in Spilková \&Fialová, 2013). Another marketing approach concerns the promotion of gastronomic regional identity (as in Bertella, 2014 and Mei et al., 2017), also anchored on touristic and gastronomic routes set in one or more regions sharing the same biophysical conditions and, often, a shared culture and tradition.

Regarding the second aspect, diverse foodscapes are analysed, as for example, traditional markets (as in Fuste-Forné (2018) regarding Costa Daurada, Barcelona), the savoir faire behind the production of traditional foods (as Yuanija village, in China, by Guan et al., 2018); 
the cheesecakes of Canterbury (Fusté-Forné, 2016); the Greek and Mediterranean gastronomy (Metaxas \& Karagiannis, 2016) and the value of indigenous-based foods and food preparation in Ecuador and Mexico (Sidali et al., 2016; Matta, 2019).

Production and commercialization networks are addressed within this dimension, featuring different combinations of stakeholders such as local food networks and the community (de Jong and Varley, 2018), drink and food producers with cultural venues (Garibaldi and Pozzi, 2018), producers and retailers (de St. Maurice, 2017), producers and tourism operators (Mei et al., 2017) and small and medium enterprises (Ermolaev, Yashalova and Ruban, 2019), again highlighting the diversity of stakeholders analysed within this field of research. Mentions of production processes and places of origin of the products are often related considering that either the production or transformation of raw materials such as food preparation and display tend to be anchored on a given tradition or local food heritage and farming practices (as for instance in Ermolaev et al., 2019 or in Kim and Ellis, 2015, regarding diverse products and settings). The emphasis on agricultural-based activities and farming practices is also important (FustéForné, 2016, 2019; Lenglet, \& Giannelloni, 2016; Mei et al., 2017; Sidali et al., 2016). These aspects emphasize the relevance of local traditional food and its links to rural provenance in food tourism experiences, in line with Figueiredo (2021) and Green \& Dougherty (2008) suggesting at the same time the positive impacts on local development (Renko et al., 2010 and Sims (2009).

\section{The impacts on rural development dimension}

The analysis of the impacts on rural development is a salient dimension in the majority (44) of the articles analysed. This is in line with Ellis et al. (2018), stressing the relevance of the geographical anchorage of food tourism. The analysis of this dimension, although depicted as a more general category than the previous one, includes aspects related to the specific features of rural territories such as food origin contexts and to the related need to preserve food heritage and traditions, as well as promoting social capital and sustainability. Regarding the first aspect, there is a focus on idiosyncratic cultural and geographic settings of food origins, which implies a diversity of approaches and topics covered, as well as geographically marked perspectives, as also advanced by Rachão et al. (2019). In fact, an almost exclusive focus on social equity and local food value protection appears to be more salient in contexts with a high concentration of indigenous populations and biodiversity values, as in the case of Mexico and Ecuador (Ardren, 2018; Matta, 2019; Sidali et al., 2016). Two interesting insights can be derived from these analyses: the gender-based roles in producing, preparing and serving local food, and the synergies of food-related activities with other cultural creations (such as handicrafts). Neither dimensions are explored in studies concerning different locations and the analysis of the different roles of women and men regarding the production and preparation of food, may constitute an especially interesting avenue for future research.

Although also interested in the contribution of social capital to rural development, Europeanbased studies mainly tend to emphasize the need to promote sustainability and sustainable development. Sustainability is often conceptualized in European articles in its first and most commonly used sense: as the compromise between economic development and preservation of place authenticity, environmental, cultural and social local resources and assets (including food), with rural and food tourism being pointed out as a possible solution to achieve sustainable development while offering local job opportunities and increasing revenues (de Salvo et al., 2013; De la Torre et al., 2014; Morales et al., 2015; Pavia et al., 2014). This conceptualization is aligned with current worldwide concerns regarding the need for sustainability in food production, commercialization and consumption (namely in tourism) (e.g., Sims, 2009). The social and governance dimension of sustainability is highlighted by analysing the role of social capital and the acknowledgment of unequal power relations (for example, in Jong \& Varley, 2018) or by examining the relevance of synergies and networks amongst the various stakeholders (producers, retailers, tourists) and institutions to local development (as in De la Torre et al., 2014 or Morales et al., 2015). The cultural dimension is analysed mainly through the relevance of cultural and historical authenticity (as in De la Torre et al., 2014), often combined with an examination of the need to preserve natural elements and environmental assets and also to preserve food traditions (as in Pavia et al., 2014). More sustainable food production and 
distribution chains and channels, namely the importance of short food supply chains for producers, retailers and consumers (as in Fusté-Forné, 2018; Garner \& Ayala, 2019; Testa et al., 2019) and the ways to promote more sustainable tourism activities and experiences (as in De la Torre et al., 2014 or Testa et al., 2019), also highlight the economic dimension of sustainability. In addition to the focus on sustainability and the ways in which food tourism may contribute to fostering sustainable development in rural territories, a few articles also discuss the role and contribution of specific food products and routes.

Asian-based studies, namely the ones set in India (as Ahlawat et al., 2019) and China (as Guan et al., 2019) or Taiwan (Liu et al., 2017), although differing in focus, show a similar concern related to sustainability, especially regarding the preservation of natural resources together with historical and cultural specificities related to food production and preparation and on offer to tourists. In the first, the concern lies in slow food tourism and the governmental measures to ensure sustainability and the social, cultural and environmental levels; in the second case they focus on the ways in which traditional food on offer to urbanites may contribute to the sustainability of rural communities mainly at the economic and governance level; and in the third, the focus is on organic farming and certification and its relationship with tourism through sustainable agri-food tourism development that may act as educational practice for sustainability of farmers and tourists. Also related to the role of sustainable production processes and producers in rural food tourism, St. Maurice (2017) analyses the appeal for tourists and the community impact of a traditional Japanese specific foodstuff - 'shishigatani kabocha', a type of squash and the role of women in the preparation process of this product, therefore highlighting (as in Ardren, 2018) gender-based practices regarding food. The study based in Russia (Ermolaev et al., 2019), takes a different path, showing an interesting distinction between what are named 'European' and 'Russian' styles of cheese tourism regarding the sustainable development of rural communities.

Finally, the studies focusing on the USA tend more often to unveil the factors underlying rural tourism development projects as in the case of Doganer (2017), who analyses the revitalization of former sites of Spanish missions, highlighting the role of agriculture and enabling immersive heritage experiences both for visitors and community members. Other studies analyse consumers' preferences for local food and drink both regarding branding and identity (as Garner \& Ayala, 2019 or Murray \& Kline, 2015) and its impacts on local development.

\section{Discussion and conclusion}

The relatively limited number of articles analysing the liaisons between food tourism and rural territories within the broader food tourism literature underlines the underexplored nature of the topic examined here. On the other hand, the diversity of approaches along with the multiple dimensions and sub-dimensions analysed by the articles reviewed, stresses the diversity imbued in the examination of the connections between food tourism and rural territories. This diversity is well expressed by the scientific areas of the journals in which the articles have been published, also attesting to the multidisciplinary character of the research on the topic, in line with the conclusions of Ellis, et al. (2018) and Everett and Aitchison (2008). Along with the multiple dimensions and sub-dimensions analysed, and stressing the diversity imbued in the examination of the connections between food tourism and rural territories, the articles deal with different samples, analysing various stakeholders and using a combination of diverse techniques and methods, both to collect and to analyse data.

Results of the systematic literature review demonstrate that food tourism (considering all the terms used to coin the connections between food and tourism) is frequently related to rural sustainable development, as well as to traditions, cultural patrimony and heritage, tourists' motivations and experiences regarding local food and to the marketing and promotion (together with commercialization) of locally produced and/or prepared foodstuffs. These findings are in line with the increasing recognition, especially by the middle of the 2000 s onwards, that rural provenance food on offer for tourists may have important social and economic positive impacts for the development of rural territories (Renko et al., 2010; Sims, 2009). In effect, the impacts on local development - often considered with the production and commercialization strategies, as well as demand issues - constitute the main dimension analysed by the selected articles, 
revealing a variety of potential virtuous bonds deriving from the connections between food tourism and rural territories. The frequent combination of these dimensions in the studies reviewed indicates that the connections between food tourism and rural territories are indeed manifold and complex (as also stressed by Ellis et al, 2018 and Henderson, 2009).

The majority of the articles scrutinized were based on studies conducted in Europe (particularly in Spain and Italy) and North America (particularly in the USA), revealing a Western and, especially, a Southern European interest in the topic. This may be connected to the current state of many Southern European rural areas that experienced long-lasting processes of demographic, social and economic decline over the last decades that have, in some areas, been just partially reversed by the development of tourism-related activities coupled with food production and commercialization (as also underlined by Figueiredo, 2021). While this may justify the larger number of studies in southern European countries, further analysis is still needed to confirm not only the greater interest of southern European researchers in the connection between food tourism and rural contexts, but also the role that food tourism has been assuming over the last few decades as a catalyst of local development. This geographically marked interest in the topic is also accompanied (partially in line with the findings of Rachão et al., 2019) by a geographically determined diversity of approaches and topics covered by the articles. The majority of the articles take food tourism approach in examining the connections with rural contexts, followed by gastronomic and culinary tourism. However, notwithstanding the fact that food tourism is often used as an umbrella term to refer to the interconnections between food, tourism and rural territories, the European-based studies reviewed here tend to adopt more to a gastronomic perspective that seems to be related with a greater attention to specific traditional products (such as olive oil) and their places of provenance, in line with Green and Dougherty (2008) and Pavlidis and Markantonatou (2020). This is contrary to the findings of Ellis et al. (2018), but in line with the conclusions of Rachão et al. (2019). The literature from the United States more often tends to embrace a culinary tourism approach which is more focused on the enhancement (and marketing) of tourists' cultural experiences through food, as also evinced by Ellis et al. (2018).

Regarding the topics covered by the articles reviewed, some geographical differences are also worth mentioning, especially regarding impacts on rural communities and rural food production and commercialization. In fact, articles dealing with Latin American contexts (such as Ecuador and Mexico) demonstrate an emphasis on social equity issues (especially regarding indigenous people) and protection of local food resources and values. European-based studies, on the other hand, tend to emphasize the need to promote sustainable rural development and tourism based on food production and commercialization, focusing on the impacts that the development of food tourism may induce. Asian-based studies, despite some differences in focus discussed above, share similar concerns in valuing and preserving local historical and cultural food specificities. Studies conducted in the USA tend to examine rural tourism development projects and consumers' preferences regarding food, and also analyse the development of regional brands and identities associated with food. Despite the different aspects tackled by the articles examined according to different cultural and geographical settings, overall it seems that the promotion of rural and local development through food-related tourism encompasses different dimensions: individual, social and environmental. At the same time, the role played by diverse actors and stakeholders at different scales is acknowledged, such as tourists, food producers and suppliers, food and tourism agencies and industries and - although to a lesser extent - local residents. As discussed before, the examination of the samples used in the selected articles reveals that the analysis of tourists and tourism industries is more frequent that the study of local residents (including farmers) even when considering the impacts of food tourism in rural territories.

Despite the diversity of issues examined in the articles, some topics of interest regarding the connections between food tourism and rural territories seem to have been left behind. Regarding the demand dimension, studies examining the overall rural tourism experience through food are not abundant. In the same vein, the exploration of the relationships between food and wine, for example, among other possibilities, through the analysis of common routes or marketing strategies, seems to be fairly absent. The assessment, in a more quantitative manner, of the economic and social impacts of food tourism on broader rural communities is seldom present in the articles reviewed. On a different note, power relations, especially but not exclusively 
regarding indigenous populations and their resources vis-à-vis tourism demands and consumption, as well as the gender-based roles in producing, preparing and serving local food, lack further empirical evidence and examination.

Although a systematic literature review, this study possesses some limitations. The first relates to the fact that only articles issued in the last six years were considered for the analysis. A consideration of previous articles could perhaps have been useful to unveil similarities and dissimilarities, as well as changes regarding the topics analysed over time. Likewise, the relationship between the topics addressed by the articles and the scientific areas would shed some more light regarding preferred approaches and dimensions scrutinized by different fields. Finally, the option of selecting articles written in languages understood by the authors, together with the option of using only one database (Scopus) for article selection, may perhaps have hampered the representativeness of the systematic review conclusions. Future systematic reviews should consider these limitations to include literature published in other languages and available in other databases.

\section{Acknowledgements}

This study was conducted in the ambit of STRINGS - Selling The Rural IN (urban) Gourmet Stores $^{3}$ - establishing new liaisons between town and country through the sale and consumption of rural products (PTDC/GES-OUT/29281/2017/ POCI-01-0145-FEDER-029281), a 3-year research project. STRINGS is funded by the POCI - Programa Operacional Competitividade e Internacionalização (COMPETE 2020, FEDER) and by Fundação para a Ciência e Tecnologia, I.P. (FCT, IP), to which the authors are grateful.

Academic references

[1] Ahlawat, M., Sharma, P. \& Gautam, P. K. (2019). Slow Food and Tourism development: a case study of slow food tourism in Uttarakhand, India. Geojournal of Tourism and Geosites, 26(3), 751-760. DOI: 30892/gtg.26306-394.

[2] Allen, A. (2017). Indigenous self-determination and the culinary tourist. Tourism, Culture and Communication, 17(2), 131-136. DOI: 10.3727/109830417X14966810027571.

[3] Anderson, T., Getz, D., Vujicic, S., Robinson, R. N. \& Cavicchi, A. (2016). Preferred travel experiences of foodies: an application of photo elicitation. Journal of Vacation Marketing, 22(1), 55-67. DOI: 10.1177/1356766715589621.

[4] Ardren, T. (2018). Now Serving Maya Heritage: Culinary Tourism in Yaxunah, Yucatan, Mexico. Food and Foodways, 26(4), 290-312. DOI: 10.1080/07409710.2018.1531216.

[5] Bertella, G. (2014). Designing small-scale sport events in the countryside. International Journal of Event and Festival Management, 5(2), 132-145. DOI: 10.1108/IJEFM-05-20130008.

[6] Bessière, J. (1998). Local development and heritage: traditional food and cuisine as tourist attractions in rural areas. Sociologia Ruralis, 38(1), 21-34. DOI: 10.1111/1467-9523.00061.

[7] Bjork, P. \& Kauppinen-Raisanen, H. (2014). Culinary- gastronomic tourism- a search for local food experiences. Nutrition \& Food Science, 44(4), 294-309. DOI: 10.1108/NFS-12-20130142.

[8] Bressan, A. \& Alonso, A. D. (2013). Cultural Institutes as Social Anchors: Implications for Tourism and Hospitality Planning and Development. Tourism Planning \& Development, 10(4), 433-450. DOI: 10.1080/21568316.2013.779315.

\footnotetext{
${ }^{3}$ https://www.stringsproject.pt/
} 
[9] Broadway, M. J. (2017). Putting Place on a Plate along the West Cork Food Trail. Tourism Geographies, 19(3), 467-482. DOI: 10.1080/14616688.2016.1276615.

[10] Busby, G., Huang, R. \& Jarman, R. (2013). The Stein Effect: An alternative film-induced tourism perspective. International Journal of Tourism Research, 15, 570-582. DOI: $10.1002 /$ jtr.1875.

[11] Campón-Cerro, A. M., Folgado-Fernandez, J. A. \& Hernandes, J. M. (2017). Rural destination development based on olive oil tourism: the impact of residents' community attachment and quality of life on their support for tourism development. Sustainability, 9(9), Art. 1624. DOI: 10.3390/su9091624.

[12] Casalegno, C., Candelo, E., Santoro, G. \& Kitchen, P. (2019). The perception of tourism in coffee-producing equatorial countries: an empirical analysis. Psychology Marketing, 37(1), 154-166. DOI: 10.1002/mar.21291.

[13] Centobelli, P. \& Ndou, V. 2019. Managing customer knowledge through the use of big data analytics in tourism research. Current Issues in Tourism, 22(15), 1862-1882. DOI: $10.1080 / 13683500.2018 .1564739$.

[14] Cohen, E. \& Avieli, N. (2004). Food in Tourism: Attraction and Impediment. Annals of Tourism Research 31(4), 755-778. DOI: 10.1016/j.annals.2004.02.003.

[15] de Jong, A. \& Varley, P. (2018). Food tourism and events as tools for social sustainability? Journal of Place Management and Development, 11(3), 277-295. DOI: 10.1108/JPMD-062017-0048.

[16] de Salvo, P., Hernández-Mogollón, J. M., Di Clemente, E. \& Calzati, V. (2013). Territory, tourism and local products. The extra virgin oil's enhancement and promotion: a benchmarking Italy - Spain. Tourism and Hospitality Management, 19(1), 23-34. DOI: $10.20867 /$ thm.19.1.2.

[17] de St. Maurice, G. (2017). Everything but the Taste: Kyoto's Shishigatani Squash as Culinary Heritage. Food, Culture \& Society, 20(2), 281-301. DOI: 10.1080/15528014.2017.1305829.

[18] de la Torre, G. M, Rojas, R. H. \& Romero, V. N. (2016). The study of gastronomic tourism in córdoba and the association of the cuisine. an econometric analysis. Tourism and Hospitality Management, 22(2), 173-191. DOI: 10.20867/thm.22.2.7.

[19] de la Torre, G., Fernández, E. M. \& Naranjo, L. M. (2014). Turismo gastronomico, denominaciones de origen y desarrollo rural en Andalúcia: situación actual. Boletin de la Associacion de Geografos Espanoles, 65, 113-137. DOI: 10.21138/bage.1746.

[20] Diaconescu, D. M., Moraru, R. \& Stănciulescu, G. (2016). Considerations on Gastronomic Tourism as a Component of Sustainable Local Development. Amfiteatru Economic, 18(10), 999-1014.

[21] Dimitrovski, D. (2016). Urban gastronomic festivals - Non-food related attributes and food quality in satisfaction construct: A pilot study. Journal of Convention and Event Tourism, 17(4), 247-265. DOI: 10.1080/15470148.2015.1136978.

[22] Doganer, S. (2017). Architectural design studio on sustainable tourism alternatives in the San Antonio Missions Historic District. Tourism and Hospitality Research, 17(3), 298313. DOI: $10.1177 / 1467358415602955$.

[23] du Rand, G. E., Heath, E. (2006). Towards a Framework for Food Tourism as an Element of Destination Marketing. Current Issues in Tourism, 9(3), 206-234. DOI: 10.2164/cit/226.0.

[24] Ellis, A., Park, E., Kim, S. \& Yeoman, I. (2018). What is food tourism? Tourism Management, 68, 250-263. DOI: 10.1016/j.tourman.2018.03.025.

[25] Enzenbacher, D. (2019). Exploring the food tourism landscape and sustainable economic development goals in Dhofar Governorate, Oman. British Food Journal, 122(6), 1897-1918. DOI: 10.1108/bfj-09-2018-0613. 
[26] Ermolaev, V., Yashalova, N., Ruban, D. (2019). Cheese as a tourism resource in Russia: The first report and relevance to sustainability. Sustainability, 11, Art. 5520. DOI: 10.3390/su11195520.

[27] Eusébio, C., Carneiro, M. J., Madaleno, M., Robaina, M., Rodrigues, V., Russo, M., Relvas, H., Gama, C., Lopes, M., Seixas, V., Borrego, C. \& Monteiro, A. (2021). The impact of air quality on tourism: a systematic literature review. Journal of Tourism Futures, $7(1), 111-130$. DOI: 10.1108/JTF-06-2019-0049.

[28] Everett, S. (2012). Production places or consumption spaces? The place-making agency of food tourism in Ireland and Scotland. Tourism Geographies, 14(4), 535-554. DOI: $10.1080 / 14616688.2012 .647321$.

[29] Everett, S. \& Aitchison, C. (2008). The role of food tourism in sustaining regional identity: a case study of Cornwall, South West England. Journal of Sustainable Tourism. 16(2), 150167. DOI: $10.2167 /$ jost696.0.

[30] Figueiredo, E. (2021). Rural Provenance Food as Cultural Heritage - a way of promoting rural attractiveness. In Oliveira, L., Amaro, A. \& Melro A., eds. Handbook of Research on Cultural Heritage and Its Impact on Territory Innovation and Development (pp. 114-137). Hershey: IGI Global. DOI: 10.4018/978-1-7998-6701-2.ch007.

[31] Folgado-Fernandez, J., Hernández-Mogollón, J. \& Duarte, P. (2017). Destination image and loyalty development: the impact of tourists' food experiences at gastronomic events. Scandinavian Journal of Hospitality and Tourism, 17(1), 92-110. DOI: 10.1080/15022250.2016.1221181.

[32] Fusté-Forné, F. (2019). Seasonality in food tourism: wild foods in peripheral areas. Tourism Geographies. DOI: 10.1080/14616688.2018.1558453.

[33] Fusté-Forné, F. (2018). Drawing a gastronomy landscape from food markets' produce. International Journal of Culture, Tourism and Hospitality Research, 12(3), 378-384.

[34] Fusté-Forné, F. (2016). Tasting cheesescapes in Canterbury (New Zealand). New Zealand Geographer, 72, 41-50. DOI: 10.1111/nzg.12115.

[35] Fusté-Forné, F. (2015). El turisme gastronòmic: autenticitat i desenvolupament local en zones rurals. Documents d'Análisi Geográfica, 61(2), 289-304. DOI: 10.5565/rev/dag.218.

[36] Garibaldi, R. \& Pozzi, A. (2018). Creating tourism experiences combining food and culture: an analysis among Italian producer. Tourism Review, 73(2), 230-241. DOI: 10.1108/TR-062017-0097.

[37] Garner, B. \& Ayala, C. (2019). Regional tourism at the farmers' market: consumers' preferences for local food products. Journal of Culture, Tourism and Hospitality Research, 13(1), 37-54. DOI: 10.1108/IJCTHR-07-2018-0095.

[38] Getz, D. \& Robinson, R. N. S. (2014). Foodies and Food Events. Scandinavian Journal of Hospitality and Tourism, 14(3), 315-330. DOI: 10.1080/15022250.2014.946227.

[39] Green, G. P. \& Dougherty, L. D. (2008). Localizing Linkages for Food and Tourism: Culinary tourism as a community development strategy. Community Development, 39(3), 148-158. DOI: $10.1080 / 15575330809489674$.

[40] Guan, J., Gao, J. \& Zhang, C. (2019). Food Heritagization and sustainable Rural Tourism Destination: The case of China's Yuanjia Village. Sustainability, 11, Art. 2858. DOI: $10.3390 /$ su11102858.

[41] Gyimóthy, S. (2017). The reinvention of terroir in Danish food place promotion. European Planning Studies, 25(7), 1200-1216. DOI: 10.1080/09654313.2017.1281229.

[42] Hall, C. M. \& Sharples, E. (2003). The consumption of experiences or the experience of consumption? An introduction to the tourism of taste. In Hall, C. M., Sharples, E., Mitchell, R., Macionis, N. \& Cambourne, B., eds., Food Tourism Around the World (pp. 1-24), London: Elsevier. 
[43] Hernandez-Mogollón, J. M., Di-Clemente, E. \& Guzmán, T. L. (2015). Culinary tourism as a cultural experience. The case study of the city of Cáceres (Spain). Boletin de la Asociacion de Geografos Espanoles, 68, 407-427.

[44] Hjalager, A-M. \& Johansen, P. H. (2013). Food tourism in protected areas - sustainability for producers, the environment and tourism? Journal of Sustainable Tourism, 21(3), 417-433. DOI: 10.1080/09669582.2012.708041.

[45] Horng, J. S. \& Tsai, C. T. (2010). Government Websites for Promoting East Asian Culinary Tourism: A Cross-National Analysis. Tourism Management, 31, 74-85. DOI: 10.1016/j.tourman.2009.01.009.

[46] lizuka, R. \& Kikuchi, T. (2016). A village of high fermentation: Brewing culture-based food tourism in Watou, West Flanders, Belgium. European Journal of Geography, 7(1), 58-72.

[47] Jimenez, J. A., de La Torre, M. G. \& Rojas, R. H. (2019). Analysis of the tourism demand for Iberian ham routes in Andalusia (Southern Spain): Tourist Profile. Sustainability, 11, Art. 4278. DOI: 10.3390/su11164278.

[48] Kim, Y., Duncan, J. \& Chung, B. W. (2015). Involvement, satisfaction, perceived value and revisit intention: a case study of a food festival. Journal of Culinary, Science and Technology, 13(2), 133-158. DOI: 10.1080/15428052.2014.952482.

[49] Kim, S. \& Ellis, A. (2015). Noodle production and consumption: from agriculture to food tourism in Japan. Tourism Geographies, 17(1), 151-167. DOI: $10.1080 / 14616688.2014 .978812$.

[50] Kim, S. \& Iwashita, C. (2016). Cooking Identity and Food Tourism: the case of Japanese udon noodles. Tourism Recreation Research, 41(1), 89-100. DOI: $10.1080 / 02508281.2016 .1111976$.

[51] Kim, Y. (2016). To find equilibrium of food festival tourism: an application of factor analysis and analytical hierarchy process. Event Management, 20(2), 135-146. DOI: 10.3727/152599516X14610017108585.

[52] Kitchenham, B. (2004). Procedures for Performing Systematic Reviews [Technical report]. Keele University.

[53] Kunasegaran, M., Rasoolimanesh, S. M. \& Khan, S. 2019. Experiences of international tourists with healthy signature foods: a case study in Malacca. British Food Journal, 122(6), 1869-1882. DOI: 10.1108/BFJ-08-2018-0567.

[54] Lai, I., Lu, D. \& Liu, Y. 2019. Experience economy in ethnic cuisine: a case of Chengdu cuisine. British Food Journal, 122(6), 1801-1817. DOI: 10.1108/BFJ-08-2018-0517.

[55] Lenglet, F. \& Giannelloni, J-L. (2016). Does a Terroir Product Tell the Same Story to Tourists, Day-trippers and Local Consumers? The Moderating Role of Variety-seeking Tendency and Perceived Authenticity. International Journal of Tourism Research, 18, 494-505. DOI: $10.1002 /$ jtr.2067.

[56] Lee, A., Wall, G. \& Kovacs, J. (2015). Creative food clusters and rural development through place branding: Culinary tourism initiatives in Stratford and Muskoka, Ontario, Canada. Journal of Rural Studies, 39, 133-144. DOI: 10.1016/j.jrurstud.2015.05.001.

[57] Liu, S., Yen, C., Tsai, K. \& Lo, W. (2017). A conceptual framework for agri-food Tourism as an eco-innovation strategy in small farms. Sustainability, 9, Art. 1683. DOI: $10.3390 /$ su9101683.

[58] Londono, M. \& Palomeque, F. L. (2017). The territorial dimension of food tourism in Catalonia (Spain). an interpretation from a relational economic geography perspective. Boletin de la Asociacion de Geografos Espanoles, 74, 93-116. DOI: 10.21138/bage.2446.

[59] Matta, R. (2019). Mexico's ethnic culinary heritage and cocineras tradicionales (traditional female cooks). Food and Foodways, 27(3), 211-231. DOI: $10.1080 / 07409710.2019 .1646481$. 
[60] Mei, X., Lerfald, M. \& Brata, H. O. (2017). Networking and collaboration between tourism and agriculture: food tourism experiences along the National Tourist Routes of Norway. Scandinavian Journal of Hospitality and Tourism, 17(1), 59-75. DOI: 10.1080/15022250.2016.1262514.

[61] Metaxas, T. \& Karagiannis, D. (2016). Culinary tourism in Greece: Can the Past define the future? Dimensions of innovation, entrepreneurship and regional development. Journal of Developmental Entrepreneurship, 21(3), 1-20. DOI: 10.1142/S1084946716500187.

[62] Mnguni, E. \& Giampiccoli, A. (2015). Indigenous food and tourism for community well-being: a possible contributing way forward. Mediterranean Journal of Social Sciences, 6(352), 24 34. DOI: $10.5901 / \mathrm{mjss} .2015 . v 6 n 3 s 2 p 24$.

[63] Mohamed, M., Hewedi, M., Lehto, X. \& Maayouf, M. (2019). Marketing local food and cuisine culture online: a case study of DMO's websites in Egypt. International Journal of Tourism cities. DOI: 10.1108/IJTC-05-2019-006.

[64] Morales, P. C., Guzman, T. L., Cuadra, S. M. \& Aguera, F. O. (2015). Analisis de la demanda del oleoturismo en Andalucia. Revista de Estudios Regionales, 104, 133-149.

[65] Murray, A. \& Kline, C. (2015). Rural tourism and the craft beer experience: factors influencing brand loyalty in rural North Carolina, USA. Journal of Sustainable Tourism, 23(8-9), 11981216. DOI: 10.1080/09669582.2014.987146.

[66] Okumus, F., Kock, G., Scantlebury, M. M. G. \& Okumus, B. (2013). Using Local Cuisines when Promoting Small Caribbean Island Destinations. Journal of Travel \& Tourism Marketing, 30(4), 410-429. DOI: 10.1080/10548408.2013.784161.

[67] Omar, R., Syed, O. R., Ning, B., Vagenas, S. \& Ali, F. (2019). Eat, work, love: alternative tourists' connection with ethnic food. British Food Journal, 122(6), 1999-2019. DOI: 10.1108/BFJ-10-2018-0699.

[68] Ottenbacher, M. C. \& Harrington, R. (2013). A case study of a culinary tourism campaign in Germany: implications for strategy making and successful implementation. Journal of hospitality \& Tourism Research, 37(1), 3-28. DOI: 10.1177/1096348011413593.

[69] Pavia, N., Gržinić, J. \& Floričić, T. (2014). The perception of gastronomic events within the framework of sustainable tourism development. WIT Transactions on Ecology and The Environment, 187, 277-289. DOI: 10.2495/ST140221.

[70] Pavlidis, G. \& Markantonatou, S. (2020). Gastronomic tourism in Greece and beyond: A thorough review. International Journal of Gastronomy and Food Science, 21, 2-10. DOI: $10.1016 /$ j.jigfs.2020.100229.

[71] Popp, L. \& McCole, D. (2016). Understanding tourists' itineraries in emerging rural tourism regions: the application of paper-based itinerary mapping methodology to a wine tourism region in Michigan. Current Issues in Tourism, 19(10), 988-1004. DOI: 10.1080/13683500.2014.942259.

[72] Prat Forga, J. M. \& Valiente, G. C. (2014). The importance of satisfaction in relation to gastronomic tourism development. Tourism Analysis, 19, 261-272. DOI: $10.3727 / 108354214 X 14029467968321$.

[73] Rachão, S., Breda, Z., Fernandes, C. \& Joukes, V. (2019). Food Tourism and regional development: A systematic literature review. European Journal of Tourism Research, 21, 33-49.

[74] Renko, S., Renko, N. \& Polonijo, T. (2010). Understanding the role of food in rural tourism development. Journal of Food Products Marketing, 16(3), 309-324. DOI: $10.1080 / 10454446.2010 .485096$.

[75] Robinson, G. \& Bingjie, S. (2019). Rural transformation: Cherry growing on the Guanzhong Plain, China and the Adelaide Hills, South Australia. Journal of Geography Science, 29(5), 675-701. DOI: 10.1007/s11442-019-1621-2. 
[76] Sidali, K. L., Huber, D. \& Schamel, G. (2017). Long-Term sustainable development of tourism in south Tyrol: an analysis of tourists' perception. Sustainability, 9, Art. 1791. DOI: $10.3390 /$ su9101791.

[77] Sidali, K. L., Morocho, P. \& Garrido-Pérez, E. (2016). Food tourism in indigenous settings as a strategy of sustainable development: The case of Ilex Guayusa Loes in the Ecuadorian Amazon. Sustainability, 8, Art. 967. DOI: 10.3390/su8100967.

[78] Sidali, K. L., Kastenholz, E. \& Bianchi, R. (2013). Food tourism, niche markets and products in rural tourism: combining the intimacy model and the experience economy as a rural development strategy. Journal of Sustainable Tourism, 23(8-9), 1179-1197. DOI: $10.1080 / 09669582.2013 .836210$.

[79] Silkes, C., Cai, L. \& Lehto, X. (2013). Marketing to the culinary tourist. Journal of Travel \& Tourism Marketing, 30(4), 335-349. DOI: 10.1080/10548408.2013.784151.

[80] Sims, R. (2009). Food, place and authenticity: local food and the sustainable tourism experience. Journal of Sustainable Tourism, 17(3), 321-336. DOI: 10.1080/09669580802359293.

[81] Shtapit, E. (2017). Exploring tourists' memorable food experiences: a study of visitors to Santa's official hometown. Anatolia - An International Journal of Tourism and Hospitality Research, 28(3), 404-421. DOI: 10.1080/13032917.2017.1328607.

[82] Sohn, E. \& Yuan, J. (2013). Who are the culinary tourists? An observation at a food and wine festival. International Journal of Culture, Tourism and Hospitality Research, 7(2), 118-131. DOI: 10.1108/IJCTHR-04-2013-0019.

[83] Spilková, J. \& Fialová, D. (2013). Culinary Tourism Packages and Regional Brands in Czechia. Tourism Geographies, 15(2), 177-197. DOI: 10.1080/14616688.2012.726268.

[84] Sotiriadis, M. (2013). Culinary tourism assets and events: suggesting a strategic planning tool. International Journal of Contemporary Hospitality Management, 27(6), 1214-1232. DOI: 10.1108/IJCHM-11-2013-0519.

[85] Teixeira, V. A. V. T. \& Ribeiro, N. F. (2013). The lamprey and the partridge: a multi-sited ethnography of food tourism as an agent of preservation and disfigurement in Central Portugal. Journal of Heritage Tourism, 8(2-3), 193-212. DOI: $10.1080 / 1743873 X .2013 .767813$.

[86] Testa, R., Galati, A., Schifani, G., di Trapani, A. \& Migliore, G. (2019). Culinary tourism experiences in agri-tourism destinations and sustainable consumption - understanding italian tourists' motivations. Sustainability, 11, Art. 4588. DOI: 10.3390/su11174588.

[87] Thomas Lane, E., Jones, R., Jones, A. \& Mitchelmore, S. (2016). Exploring the potential of local food and drink entrepreneurship in rural Wales. Local Economy, 31(5), 602-618. DOI: $10.1177 / 0269094216654669$.

[88] Vera-Baceta, MA., Thelwall, M. \& Kousha, K. (2019). Web of Science and Scopus language coverage. Scientometrics 121, 1803-1813. DOI: 10.1007/s11192-019-03264-z.

[89] Updhyhay, Y. \& Sharma, D. (2014). Culinary preferences of foreign tourists in India. Journal of Vacation Marketing, 20(1), 29-39. DOI: 10.1177/1356766713486143.

[90] Xiao, Y. \& Watson, M. (2019). Guidance on Conducting a Systematic Literature Review. Journal of Planning Education and Research, 39(1), 93-112. DOI: $10.1177 / 0739456 \times 17723971$.

[91] Yang, L., Lai, B. \& Xiao, H. (2019). The metaphor of sadness: Hakka's Bean Jelly as culture and consumption through tourism, Tourism Geographies, 21(1), 102-120. DOI: $10.1080 / 14616688.2018 .1449238$. 